\title{
Resveratrol Content of Muscadine Berries is Affected by Disease Control Spray Program
}

\author{
J.B. Magee and B.J. Smith \\ U.S. Department of Agriculture, Agricultural Research Service, Small Fruit \\ Research Station, P.O. Box 257, Poplarville, MS 39470
}

\section{Agnes Rimando}

U.S. Department of Agriculture, Agricultural Research Service, Natural Products Utilization Research Unit, P.O. Box 8048, University, MS 38677

Additional index words. Vitis rotundifolia, disease scores, fungicides, phytoalexin, stilbene

\begin{abstract}
Control of muscadine diseases is necessary to minimize yield loss and is especially important for highest quality fresh-market berries. In a systematic disease control spray program, four fungicides registered for grapes were applied sequentially at 10- to 20-day intervals from early bloom until just before harvest to five muscadine cultivars. Objectives of the study were to: 1 ) determine the effects of the spray schedule on foliage and berry diseases; and 2) study the relationship between disease incidence and resveratrol content of the berries. Resveratrol, a phytoalexin, has shown potential value in prevention and treatment of cardiovascular disease and certain cancer processes. Foliar diseases were rated visually twice during the season. Berry disease ratings were made at harvest. All fungal foliage and berry diseases were significantly reduced by fungicide treatments. Resveratrol was determined separately on berry skins, seed and pulp/juice by gas chromatography/mass spectroscopy (GC/MS). Overall, resveratrol levels in berry skins from unsprayed vines were much higher than those of sprayed vines. Concentrations varied by cultivar and within cultivar by treatment. The relationship between resveratrol concentration in skins and total disease score or scores of specific diseases was not established. Seed resveratrol concentrations differed by cultivar but were not affected by the fungicide treatments. Resveratrol concentration of seed was lower than that of skins. Accumulation of resveratrol in juice/pulp was much lower than in skins and seeds.
\end{abstract}

Muscadine grapes (Vitis rotundifolia Michx.) are native to the southeastern United States and have been cultivated in this area for more than 400 years (Olien, 1990). They are enjoying a resurgence of consumer interest because recent research has shown that muscadines and muscadine products contain resveratrol (Ector et al., 1996; McMurtrey and Watkins, 1997; Threlfall et al., 1999), a phenolic compound which may prove beneficial in nutritional and chemopreventative treatment of cardiovascular disease and cancer. Resveratrol (trans-3,5,4'-trihydroxystilbene) has favorably affected processes implicated in cardiovascular disease; it lowers serum lipids (Arichi et al., 1992), inhibits platelet aggregation in the blood (Kimura et al., 1985; PaceAsciak et al., 1995) and inhibits oxidation of human low-density lipoprotein (Frankel et al., 1993). The potential value of resveratrol in prevention and treatment of cancer has been suggested by various laboratory assays in which resveratrol has inhibited cellular events associated with tumor initiation, promotion and

Received for publication 22 Jan. 2001. Accepted for publication 22 June 2001. Mention of a trademark, proprietary product, or vendor does not constitute a guarantee or warranty of the product by the U.S. Dept. of Agriculture and does not imply its approval to the exclusion of other products that also may be suitable. progression, the three major stages of carcinogenesis (Jang et al., 1997; Jang and Pezzuto, 1999; Mgbonyebi et al., 1998).

Stilbenes, including resveratrol, are found in a number of plant families and generally are considered to be phytoalexins, i.e., compounds produced by the plant as a defense response to disease challenge or other stress. Resveratrol production by Vitis sp. in response to fungal infection was first reported by Langcake and Pryce (1976); they also noted that ultraviolet (UV) irradiation and mechanical injury could induce resveratrol production in leaves and fruit of Vitis sp. Dai et al. (1995) demonstrated that resveratrol was involved in the response of 'Carlos' muscadine leaves to infection by the downy mildew fungus Plasmopara viticola (Berk. \& Curt.) Berl \& de Ton. The association between stilbene phytoalexins and disease resistance in Vitis has been well-documented by Dercks et al. (1995).

While muscadines generally are less susceptible to diseases than are bunch grapes (Clayton, 1975), the warm humid weather of the southeastern United States favors development of fungi that cause fruit and foliar diseases. Foliar diseases such as bitter rot leaf spot [caused by Greenaria uvicola (Berk. \& Curt.) Punithalingam (syn. Melanconium fuligineum (Scribner \& Viala) Cav.)] and angular leaf spot [caused by Mycosphaerella angulata Jenkins (anamorph Cercospora brachypus Ell. \& Ev.)] (Pearson and Goheen, 1988) can significantly reduce vigor of susceptible cultivars. Bitter rot is the most important berry disease of muscadines in south Mississippi (Kummuang et al., 1996). Macrophoma rot [caused by Botryosphaeria dothidea (Moug. ex Fr.) Ces. \& deNot. (syn. B. ribis Gross. \& Duggar, anamorph Macrophoma sp.)] and ripe rot [caused by Colletotrichum gloeosporioides (Penz.) Penz. \& Sacc. (teleomorph Glomerella cingulata (Stonem.) Spauld. \& Schrenk), and C. acutatum Simmonds ex Simmonds] may cause significant losses of some cultivars. Black rot [caused by Guignardia bidwellii (Ellis) Viala \& Ravaz f. muscadinii Luttrell (anamorph Phyllosticta ampelicida (Engleman) Van der Aa)], and russet (etiology unknown) are both detract from the appearance of the fruit but do not affect fruit quality (Kummuang et al., 1996; Pearson and Goheen, 1988).

Control of muscadine fruit diseases is necessary to minimize yield loss and is especially important to ensure the highest quality freshmarket berries. In a 1997 study to select fungicides for a field study of berry disease control, four muscadine cultivars whose fruit were nearing ripeness $(\approx 2$ weeks before harvest) were treated with single applications of several individual fungicides. Fruit composition data from this study (not shown) indicated the resveratrol content was affected by the incidence of berry diseases. The objectives of this study were to: 1) determine the effects of the spray program on muscadine foliage and berry diseases; and 2) study the relationship between the incidence of berry diseases and residual resveratrol content of field-grown berries at harvest.

\section{Materials and Methods}

Five muscadine cultivars in the U.S. Dept. of Agriculture, Agricultural Research Service (USDA-ARS) Small Fruit Research Station vineyards in McNeill, Miss., were selected on the bases of fruit color and estimated overall disease reaction to the five major berry diseases $(\mathrm{S}=$ susceptible, $\mathrm{I}=$ intermediate, and $\mathrm{R}$ $=$ resistant). Light-fruited cultivars were 'Summit' (R), 'Higgins' (S), and 'Carlos' (I). Darkfruited cultivars were 'Noble' (R), and 'Cowart' (S). The vines were part of a cultivar study planted in 1990 in a randomized completeblock design with four replications. Each plot consisted of a single vine trained to a Geneva double curtain trellis, 6-m arms. All vines were drip-irrigated and maintained under cultural practices recommended by the Mississippi State Univ. Cooperative Extension Service.

Throughout the 1998 growing season, vines of these cultivars were treated under a systematic fungicide spray program recommended by the Mississippi Cooperative Extension Service. The recommended spray program used sequential applications of four fungicides labeled for grapes (Table 1) Fungicides were applied nine times at 10 - to 20-d intervals from early bloom until just before harvest with a tractor-mounted air blast mist sprayer. Con- 
Table 1. Fungicide spray schedule for muscadines, McNeill, Miss., 1998

\begin{tabular}{lcccc}
\hline \hline Date & Fungicide & Formulation & Manufacturer & ${\mathrm{Kg} \cdot \mathrm{ha}^{-1}}^{-}$ \\
\hline 8 May & Myclobutanil & Nova 40W & Rhom \& Haas & 0.28 \\
8 June & Captan & Captan 50-WP & Micro Flo & 4.48 \\
19 June & Azoxystrobin & Abound & Zeneca & 0.84 \\
29 June & Myclobutanil & Nova 40W & Rhom \& Haas & 0.28 \\
10 July & Benomyl & Benlate 50-WP & DuPont & 1.12 \\
20 July & Azoxystrobin & Abound & Zeneca & 0.84 \\
29 July & Captan & Captan 50-WP & Micro Flo & 4.48 \\
10 Aug. & Azoxystrobin & Abound & Zeneca & 0.84 \\
20 Aug. & Captan & Captan 50-WP & Micro Flo & 4.48 \\
\hline
\end{tabular}

trol vines received no fungicides.

Foliar disease ratings were made twice during the season using a visual rating scale. Symptoms of bitter rot leaf spot, black rot leaf spot, angular leaf spot and Pierce's disease were rated on a scale of $0=$ no symptoms to $5=$ severe symptoms.

Ripe berries were hand-harvested into field lugs. Two random 1-L samples were taken from each lug for disease ratings and chemical analyses. Using a system developed by Smith (Kummuang et al., 1996), two independent observers scored 25 berries individually for berry rot diseases and other blemishes on a scale of $0=$ no symptoms, $1=$ very mild symptoms, $2=$ moderate symptoms, and $3=$ severe symptoms. Berries rated 3 were inedible and considered as culls. The disease score assigned was a function of symptoms visible on the berries' skins; only in advanced stages would the disease symptoms involve the underlying pulp.

Berries for resveratrol analysis were cut in half longitudinally, seeds removed and pulp and free-flowing juice separated from the skins by finger pressure. Pulp/juice samples were frozen and lyophyllized. Skins and seeds were rinsed with deionized water, dried at $35^{\circ} \mathrm{C}$ under forced-air draft, and ground to a fine powder in a laboratory mill. All three dried components were held at $-20{ }^{\circ} \mathrm{C}$ until analyzed.

Samples were extracted for resveratrol analysis using a procedure similar to that described by Dercks and Creasy (1989). One gram of sample was homogenized (Brinkman PT1035) for $30 \mathrm{sec}$ in $20 \mathrm{~mL}$ of $80 \%(\mathrm{v} / \mathrm{v})$ methanol. The homogenate was sonicated $30 \mathrm{~min}$ and centrifuged at $2000 \mathrm{~g}$ for $20 \mathrm{~min}$. The supernatant was transferred to a graduated conical tube and concentrated to $4 \mathrm{~mL}$ by evaporating the methanol in a water bath at $40{ }^{\circ} \mathrm{C}$ under nitrogen. Six mL of $3 \% \mathrm{NaHCO}_{3}$ was added and the aqueous phase extracted twice with $10 \mathrm{~mL}$ of ethyl acetate. The ethyl acetate fractions were combined and evaporated to dryness under nitrogen at $40{ }^{\circ} \mathrm{C}$.

Resveratrol was analyzed by GC/MS (Hewlett-Packard 5989A mass spectrometer coupled to a Hewlett-Packard 5890 Series II gas chromatograph, Palo Alto, Calif.) with a DB5.625 capillary column (J\&W Scientific, Folsom, Calif.), $30 \mathrm{~m}$ long $\times 0.25 \mathrm{~mm}$ I.D. $\times$ $0.25 \mu \mathrm{m}$ film. One $\mu \mathrm{L}$ (splitless) injection of derivatized solution was made with the following temperature conditions: injection port held constant at $250^{\circ} \mathrm{C}$, oven temperature held at $120^{\circ} \mathrm{C}$ for $1 \mathrm{~min}$ then ramped at $20^{\circ} \mathrm{C} / \mathrm{min}$ to $325^{\circ} \mathrm{C}$ and held at this temperature for $5 \mathrm{~min}$.
The ion source was at $250^{\circ} \mathrm{C}$ and the quadruple at $100^{\circ} \mathrm{C}$. Helium at a flow rate of $1.8 \mathrm{~mL} / \mathrm{min}$ was the carrier gas. The retention time of derivatized standard resveratrol at these conditions was $12.10 \pm 0.02 \mathrm{~min}$.

Dried muscadine extracts were dissolved in methanol and $50-\mu \mathrm{L}$ aliquots were dried under nitrogen and treated with $100 \mu \mathrm{L}$ of $1: 1$ dimethylformamide: N,O-bis-(trimethylsilyl)trifluoroacetamide (Pierce, Rockford, Ill.). The solutions were heated at $70{ }^{\circ} \mathrm{C}$ for 30 min prior to injection. Resveratrol was quantified on the tris-trimethylsilyl derivative $\mathrm{m} / \mathrm{z}$ 444. Solutions of resveratrol (Sigma, St. Louis) in $\mathrm{MeOH}$ were prepared for the calibration curve, and $50 \mu \mathrm{L}$ of each was treated in the same fashion as were the samples. For each sample, resveratrol peak area was measured and resveratrol concentration calculated from the standard curve. Concentration of resveratrol is reported in $\mu \mathrm{g} \cdot \mathrm{g}^{-1}$ on a dry weight basis for each component.

The study was conducted in a randomized complete block design, and data were analyzed by the Statistical Analysis Systems general linear means procedure (SAS Institute, Cary, N.C.). Foliar and berry disease means were separated by Fisher's least significant difference (LSD), $P \leq 0.05$, calculated on square root +0.5 transformed disease severity data (Tables 2 and 3).

\section{Results and Discussion}

Disease control. All fungal foliar disease scores were reduced by the full season fungicide treatment (Table 2). Scores of Pierce's disease (caused by the bacterium, Xylella fastidiosa Wells et al.) on the foliage were not reduced. Late-season foliar disease scores of fungicide-treated vines were much lower than symptoms to $5=$ severe. are shown. those of untreated vines, probably because the sequential fungicide applications reduced the amount of inoculum available for new infections. While 'Noble' fruit is resistant, 'Noble' vines received the highest total foliar disease score, while 'Cowart' and 'Summit' vines received the lowest. The only significant interaction between cultivar and treatment on foliar diseases was for angular leaf spot in which 'Noble' unsprayed vines received a higher disease score than the other cultivars. Fungicide-treated vines of all cultivars had very low disease scores for angular leaf spot.

The full season fungicide treatment reduced all fungal fruit disease scores (Table 3), again probably because of reduced inoculum pressure. Scores for russet on berries were not reduced. Treated vines had more fruit without visible disease symptoms and fewer inedible berries than untreated vines. 'Higgins' fruit (bronze) from untreated vines had the highest scores for bitter rot, ripe rot, Macrophoma rot, and total berry rots, affirming its inclusion in the study as a susceptible cultivar. Fruit from untreated vines of 'Noble' (selected as resistant) had the lowest total berry rots score. The other three cultivars were rated intermediate in resistance. Fungicide treatments reduced the total berry disease score of 'Higgins' by almost 50\%. Bitter rot scores of 'Higgins', 'Carlos', 'Summit', and 'Cowart' were lower on fruit from fungicide treated vines than on fruit from untreated vines. Ripe rot scores of the three light-colored cultivars were reduced by fungicide treatments, while no symptoms of ripe rot were seen on berries of the darkfruited cultivars, Cowart and Noble. In scoring disease incidence on light vs. dark fruit, a possible bias could have been introduced because small disease lesions, typically black or dark, were more difficult to see on the darkerskinned fruit. 'Noble' fruit was particularly difficult to score because of its small size and black color. Fungicide treatments also reduced Macrophoma rot scores by about two-thirds for 'Higgins' and 'Summit'. Regular fungicide applications during the growing season will reduce the incidence of fruit and foliar diseases.

Resveratrol, skins. Resveratrol concentrations of muscadine skins varied by cultivar and treatment (Fig. 1). Skins of berries from fungicide-treated vines of each cultivar were lower in resveratrol concentrations than skins

Table 2. Cultivar and fungicide treatment effects on foliar disease scores ${ }^{\mathrm{z}}$ of muscadines.

\begin{tabular}{lccccc}
\hline Cultivar/ & Bitter rot & Black rot & $\begin{array}{c}\text { Angular } \\
\text { leaf spot }\end{array}$ & $\begin{array}{c}\text { Pierce's } \\
\text { disease }\end{array}$ & Total \\
Treatment & $3.3 \mathrm{a}^{y}$ & $0.6 \mathrm{ab}$ & 2.1 & $0.9 \mathrm{a}$ & $7.0 \mathrm{a}$ \\
Noble & $2.4 \mathrm{bc}$ & $1.4 \mathrm{a}$ & 0.6 & $0.0 \mathrm{~b}$ & $4.4 \mathrm{~b}$ \\
Higgins & $2.6 \mathrm{ab}$ & $0.6 \mathrm{ab}$ & 0.0 & $0.2 \mathrm{~b}$ & $3.4 \mathrm{~b}$ \\
Carlos & $1.8 \mathrm{c}$ & $0.4 \mathrm{~b}$ & 0.1 & $0.0 \mathrm{~b}$ & $2.3 \mathrm{c}$ \\
Cowart & $1.0 \mathrm{~d}$ & $0.3 \mathrm{~b}$ & 0.2 & $0.0 \mathrm{~b}$ & $1.4 \mathrm{~d}$ \\
Summit & $2.9 \mathrm{a}$ & $1.0 \mathrm{a}$ & $1.0 \mathrm{a}$ & 0.2 & $5.2 \mathrm{a}$ \\
\hline Control & $1.6 \mathrm{~b}$ & $0.4 \mathrm{~b}$ & $0.3 \mathrm{~b}$ & 0.3 & $2.5 \mathrm{~b}$ \\
Fungicide & & &
\end{tabular}

${ }^{2}$ Disease severity rated on entire vine for each foliar disease on a visual scale of $0=$ no

${ }^{y}$ Means followed by different letters within a column and within cultivar and treatment are significantly different $(P=0.05)$ based on Fisher's LSD, calculated on square root +0.5 transformed disease severity data. Only the untransformed mean disease scores 
Table 3. Disease score ${ }^{z}$, percentage culls (unmarketable or inedible) muscadine berries, and percentage with no visible symptom at harvest following season-long fungicide treatments.

\begin{tabular}{|c|c|c|c|c|c|c|c|}
\hline $\begin{array}{l}\text { Cultivar/ } \\
\text { Treatment }\end{array}$ & Total & Bitter rot & Russet & $\begin{array}{l}\text { Ripe } \\
\text { rot }\end{array}$ & $\begin{array}{l}\text { Macrophoma } \\
\text { rot }\end{array}$ & $\begin{array}{c}\text { Culls } \\
(\%)\end{array}$ & $\begin{array}{c}\text { None } \\
(\%)\end{array}$ \\
\hline \multicolumn{8}{|l|}{$\overline{\text { Carlos }}$} \\
\hline Control & 2.1 & $0.7 \mathrm{a}^{\mathrm{y}}$ & 0.5 & 0.6 & 0.1 & 1.1 & 3.1 \\
\hline Fungicide & 1.7 & $0.3 \mathrm{~b}$ & 0.6 & 0.4 & 0.0 & 0.1 & 4.4 \\
\hline \multicolumn{8}{|l|}{ Cowart } \\
\hline Control & 2.0 & $0.5 \mathrm{a}$ & 0.9 & 0.0 & 0.2 & 2.3 & $2.7 \mathrm{~b}^{\mathrm{x}}$ \\
\hline Fungicide & 1.5 & $0.1 \mathrm{~b}$ & 0.9 & 0.0 & 0.1 & 0.4 & 3.9 \\
\hline \multicolumn{8}{|l|}{ Higgins } \\
\hline Control & $3.1 \mathrm{a}$ & $0.9 \mathrm{a}$ & 0.4 & 0.7 & $0.7 \mathrm{a}$ & $7.7 \mathrm{a}$ & 1.7 \\
\hline Fungicide & $1.8 \mathrm{~b}$ & $0.2 \mathrm{~b}$ & 0.5 & 0.4 & $0.2 \mathrm{~b}$ & $0.4 \mathrm{~b}$ & 4.4 \\
\hline \multicolumn{8}{|l|}{ Noble } \\
\hline Control & 0.8 & 0.0 & 0.4 & 0.0 & $0.1 \mathrm{a}$ & 0.4 & 9.8 \\
\hline Fungicide & 0.7 & 0.0 & 0.5 & 0.0 & $0.0 \mathrm{~b}$ & 0.3 & 10.8 \\
\hline \multicolumn{8}{|l|}{ Summit } \\
\hline Control & $2.3 \mathrm{a}$ & 0.7 & 0.6 & $0.4 \mathrm{a}$ & $0.5 \mathrm{a}$ & $1.3 \mathrm{a}$ & $1.0 \mathrm{~b}$ \\
\hline Fungicide & $1.3 \mathrm{~b}$ & 0.4 & 0.5 & $0.2 \mathrm{~b}$ & $0.1 \mathrm{~b}$ & $0.1 \mathrm{~b}$ & 4.5 \\
\hline \multicolumn{8}{|c|}{$\begin{array}{l}\text { Main effect due to } \\
\text { fungicide treatment }\end{array}$} \\
\hline Control & $2.0 \mathrm{a}$ & $0.5 \mathrm{a}$ & 0.6 & $0.3 \mathrm{a}$ & $0.3 \mathrm{a}$ & $2.4 \mathrm{a}$ & $3.9 \mathrm{~b}$ \\
\hline Fungicide & $1.4 \mathrm{~b}$ & $0.2 \mathrm{~b}$ & 0.6 & $0.2 \mathrm{~b}$ & $0.1 \mathrm{~b}$ & $0.3 \mathrm{~b}$ & $5.6 \mathrm{a}$ \\
\hline
\end{tabular}

${ }^{2}$ Disease severity rated at harvest on 25 berries by two independent observers on a scale of $0=$ no symptoms to $3=$ severe symptoms, berry inedible.

${ }^{y}$ Means followed by different letters within a column are significantly different $(P=0.05)$ based on Fisher's LSD, calculated on square root +0.5 transformed disease severity data. Only the untransformed mean disease scores are shown.

${ }^{\mathrm{x}}$ Cultivar treatment means separated by LSD $P \leq 0.05$.

from untreated vines; the differences were significant in 'Noble', 'Summit' and 'Cowart'. Overall, resveratrol concentration of skins from fungicide-treated vines was lower than that of unsprayed vines, 1.33 and $4.34 \mu \mathrm{g} \cdot \mathrm{g}^{-1}$, respectively. Since resveratrol is a phytoalexin, sprayed berries may have had lower resveratrol concentrations because fungicide treatments reduced the inoculum available on the fruit to elicit its production. Inoculum density was shown to be directly related to stilbene accumulation in leaves of Vitis sp. (Dercks and Creasy, 1989). While we found no reports describing the effects of fungicide treatment on resveratrol content of muscadine berries, the effects of fungicide treatment on resveratrol content of other Vitis grapes can be inferred from unpublished data cited by Dercks et al. (1995). They noted that experimental wines made from grapes of fungicide-treated plots were lower in resveratrol than those from grapes of untreated plots. While enological variables can affect resveratrol levels of wines (Castellari, et al., 1998; Threlfall et al., 1999), a wine's resveratrol concentration typically reflects that of the grapes from which it was made.

Unsprayed berries of each cultivar, while exposed to the same stimuli, accumulated resveratrol at different levels; resveratrol levels of fungicide-treated berries were lower, with only the very low value for 'Carlos' being different (Fig. 1). Muscadine cultivars have different capacities to produce resveratrol in response to fungal challenge as was noted among cultivars of other Vitis sp. Resistance to infection by Botrytis cinerea Pers. was closely related to the capacity of the plant to produce resveratrol and related stilbenes (Dercks and Creasy, 1989; Douillet-Breuil et al. 1999).

Berries were infected naturally in the field, and the lesions by which berries were scored for diseases developed after infection and were persistent. Symptoms of two or more diseases on the same berry were common. Date of infection was unknown, so resveratrol levels detected at harvest may not reflect the total amount produced in response to infection during the growing season. Resveratrol concentration in grapes increased after infection and then declined; concentration also declined as berries ripened (Bavaresco et al.,1997; Creasy and Coffee, 1988; Jeandet et al., 1991). Because cultivars differ in their capacity to produce and/or accumulate resveratrol, relation-

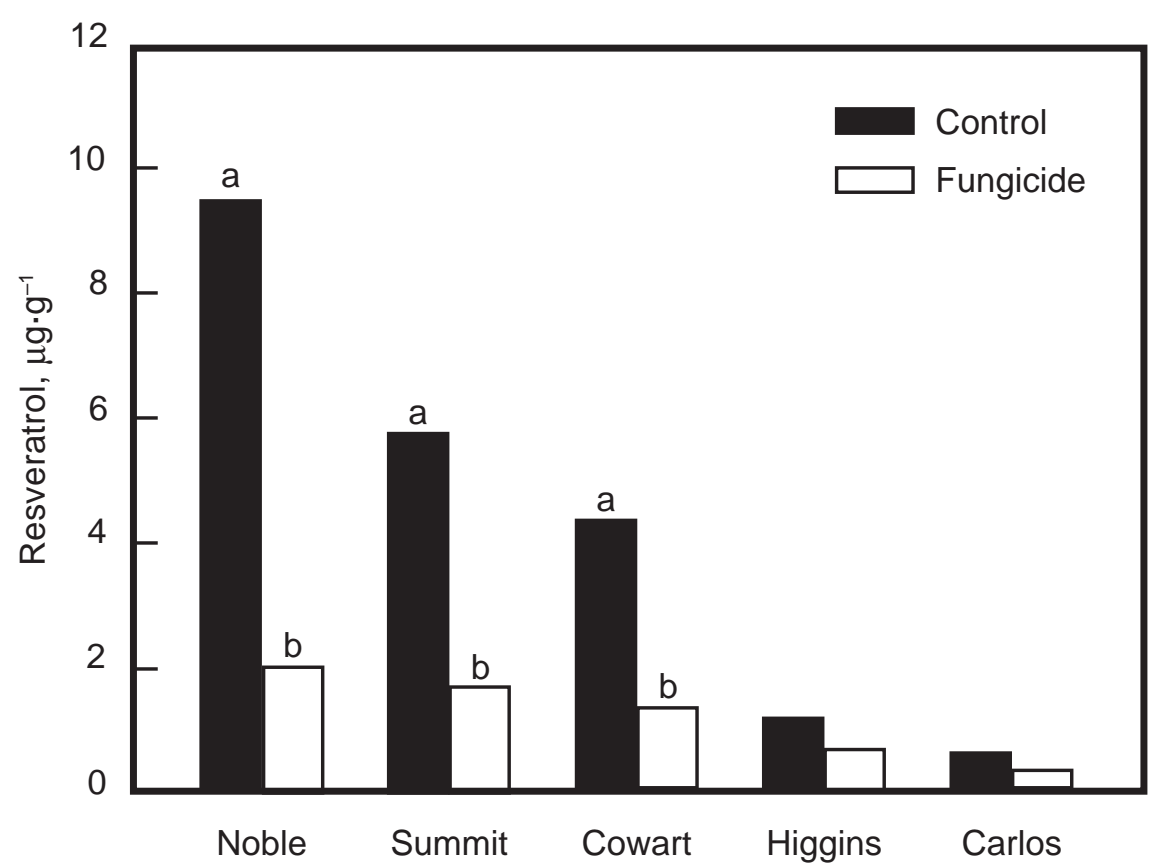

Fig. 1. Resveratrol concentrations $\left(\mu \mathrm{g} \cdot \mathrm{g}^{-1}\right)$ in skins of berries from fungicide-treated and control vines of muscadine cultivars Carlos, Cowart, Higgins, Noble, and Summit. Means separated within cultivars by LSD, $P \leq 0.05$. ships of resveratrol concentration at harvest and scores of specific diseases were not apparent. While a cause-and-effect relationship was not established, skin resveratrol levels (Fig. 1) and total disease scores of unsprayed fruit (Table 3) were moderately positively correlated $(r=-0.77, P \leq 0.12$ by SAS PROC CORR). The correlation coefficient improved $(r=-0.96, P \leq 0.04)$ when 'Carlos' was dropped from the calculation.

Resveratrol, seeds. Stilbenes are found in the woody tissues of many plant species, and resveratrol is a constituent of lignified grapevine stem tissue (Langcake and Pryce, 1976). Hardness of grape seed is a result of lignification of the integument. Resveratrol concentrations of seeds differed by cultivar (data not shown) but were not affected by the fungicidal spray program; seed resveratrol probably was not elicited by fungal challenge. Mean resveratrol concentration of seeds $\left(0.83 \mu \mathrm{g} \cdot \mathrm{g}^{-1}\right)$ was significantly lower than that of skins $\left(2.84 \mu \mathrm{g} \cdot \mathrm{g}^{-1}\right)$. Only in 'Carlos' was the seed concentration $\left(0.69 \mu \mathrm{g} \cdot \mathrm{g}^{-1}\right)$ greater than its skin concentration $\left(0.33 \mu \mathrm{g} \cdot \mathrm{g}^{-1}\right)$. Seed and skin concentrations were not highly correlated within cultivars; among the five cultivars, 'Noble' seed had the lowest concentration while 'Noble' skins had the highest. These seed concentrations were much lower than those reported by Ector et al. (1996) for bronzeand dark-fruited muscadines, but were within the ranges reported by Jeandet et al. (1995) in seed of healthy 'Pinot', 'Chardonnay', and 'Gamay' grapes.

Resveratrol, juice. Resveratrol was detected at very low concentrations $\left(<0.03 \mu \mathrm{g} \cdot \mathrm{g}^{-1}\right.$ dry weight) in the pulp/juice fraction of each cultivar and treatment except for unsprayed 'Noble' which was $0.167 \mu \mathrm{g} \cdot \mathrm{g}^{-1}$. We believe the higher concentration was the result of 
carry-over from the skins rather than from synthesis in the pulp/juice. 'Noble' berries are much smaller than those of the other four cultivars and the juice/skin contact when the berries were squeezed would have been greater. While Ector et al. (1996) reported higher juice levels, their muscadine juice was obtained by pressing which could have resulted in more resveratrol being expressed from the skins than we obtained from light finger pressure. We found no reports of significant resveratrol synthesis in the flesh of other Vitis sp.

In summary, full season treatment with a systematic fungicide spray program significantly reduced the incidence of foliar and fruit diseases of muscadine grapes. Treatment effects may have been more pronounced had the disease pressure not been lower than previous years because of very low rainfall. Fungicidetreated fruit were of higher visual quality because of lower disease incidence, but had lower resveratrol concentrations. Further work will include studying how horticultural practices (fungicides, foliar feeding, etc.) interact with muscadine fruit and foliar diseases to affect fruit yield, quality and content of phenolic phytochemicals.

\section{Literature Cited}

Arichi, H., Y. Kimura, H. Okuda, K. Baba, M. Kozawa, and S. Arichi. 1982. Effects of stilbene components of the roots of Polygonum cuspidatum Sief et Zucc. on lipid metabolism. Chem. Phar. Bul. 30:1766-1770.

Bavaresco, L., D. Petegolli, E. Cnatu, M. Fregoni, G. Chiusa, and M. Trevisan. 1997. Elicitation and accumulation of stilbene phytoalexins in grapevine berries infected by Botrytis cinerea. Vitis 36:77-83.

Castellari, M., U. Spinabelli, C. Riponi, and A. Amati. 1998. Influence of some technological practices on the quantity of resveratrol in wine.
Z Lebensm Unters Forsch A 206:151-155.

Clayton, C.N. 1975. Diseases of muscadine and bunch grapes in North Carolina and their control. North Carolina Agr. Expt. Sta. Bul. 451.

Creasy, L.L. and M. Coffee. 1988. Phytoalexin production potential of grape berries. J. Amer. Soc. Hort. Sci. 113:230-234.

Dai, G.H., C. Andary, L. Mondolot-Cosson, and D. Bourals. 1995. Histochemical studies of the interaction between three species of grapevine, Vitis vinifera, $V$. rupestris and $V$. rotundifolia and the downy mildew fungus, Plasmopara viticola. Physiol. Mol. Plant Pathol. 45:177188.

Dercks, W. and L.L. Creasy. 1989. The significance of stilbene phytoalexins in the Plasmopara viticola-grapevine interaction. Physiol. Mol. Plant Pathol. 34:189-202.

Dercks, W., L.L. Creasy, and C.J. Luczka-Bayles. 1995. Stilbene phytoalexins and disease resistance in Vitis, p. 287-315. In: M. Daniel and R.P. Purkayastha (eds.). Handbook of phytoalexin metabolism and action. Marcel Decker, New York.

Douillet-Breuil, A-c., P. Jeandet, M. Adrian, and R. Bessis. 1999. Changes in the phytoalexin content of various Vitis spp. in response to ultraviolet C elicitation. J. Agr. Food Chem. 47:44564461.

Ector, B.J., J.B. Magee, C.P. Hegwood, and M.J. Coign. 1996. Resveratrol concentration in muscadine berries, juice, pomace, purées, seeds, and wines. Amer. J. Enol. Viticult. 47:57-62.

Frankel, E.N., A.L. Waterhouse, and J.E. Kinsella. 1993. Inhibition of human LDL oxidation by resveratrol. Lancet 341:1103-1104.

Jang, M., L. Cai, G.O. Udeani, K.V. Slowing, C.F. Thomas, C.W.W. Beecher, H. H. S. Fong, N. R. Farnsworth, A.D. Kinghorn, R.G. Mehta, R.C. Moon, and J.M. Pezzuto. 1997. Cancer chemopreventive activity of resveratrol, a natural product derived from grapes. Science 275 (10 Jan):218-220

Jang, M.L and J.M. Pezzuto 1999. Cancer chemopreventative activity of resveratrol. Drug Exp. Can. Res. 25:(2-3)65-77.
Jeandet, P., R. Bessis, and B. Gautheron. 1991 The production of resveratrol (3,5,4'-trihydroxystilbene) by grape berries in different developmental stages. Amer. J. Enol. Viticult. 42:41-46.

Jeandet, P., R. Bessis, and M. Sbaghi. 1995. Production of the phytoalexin resveratrol by grape as a response to Botrytis attack under natural conditons. J. Phytopathol. 143:135-139.

Kimura, Y., H. Okuda, and S. Arichi. 1985. Effects of stilbenes on arachidonate metabolism in leukocytes. Biochim. Biophys. Acta. 834:275-278.

Kummuang, N., B.J. Smith, S.V.Diehl, and C.H. Graves, Jr. 1996. Muscadine grape berry rot diseases in Mississippi: Disease identification and incidence. Plant Dis. 80:238-243.

Langcake, P. and R.J. Pryce. 1976. The production of resveratrol by Vitis vinifera and other members of the vitaceae as a response to infection or injury. Physiol. Plant Pathol. 9:77-86.

McMurtrey, K.D. and T.R. Watkins. 1997. Resveratrol in wine, p. 44-55. In: T.R. Watkins (ed). Wine: Nutritional and therapeutic benefits. ACS Symp. Ser. 661. Amer. Chem. Soc., Washington, D.C.

Mgbonyebi, O.P., J. Russo, and I. H. Russo. 1998. Antiproliferative effect of synthetic resveratrol on human breast epithelial cells. Int. J. Oncol. 12:865-869.

Olien, W.C. 1990. The muscadine grape: Botany, viticulture, history and current industry. HortScience 25:732-739.

Pace-Asciak, C.R., S. Hahn, E.P. Diamandis, G. Soleas, and D.M. Goldberg. 1995. The red wine phenolics trans-resveratrol and quercetin block human platelet aggregation and eicosanoid synthesis: Implications for protection against coronary heart disease. Clin. Chim. Acta 235:207-219.

Pearson, R.C. and A.C. Goheen (eds.). 1988. Compendium of grape diseases. Amer. Phytopathol. Soc., St. Paul, Minn.

Threlfall, R.T., J.R. Morris, and A. Mauromoustakos. 1999. Effect of variety, ultraviolet light exposure, and enological methods on the transresveratrol level of wine. Amer. J. Enol. Viticult. 50(1):57-64. 